\title{
Laryngeal Cancer pN3b TNM Finding v8
}

National Cancer Institute

\section{Source}

National Cancer Institute. Laryngeal Cancer pN3b TNM Finding v8. NCI Thesaurus. Code C133149.

Laryngeal cancer with metastasis in a single ipsilateral lymph node, more than $3 \mathrm{~cm}$ in greatest dimension and $\mathrm{ENE}(+)$; or metastases in multiple ipsilateral, contralateral, or bilateral lymph nodes and any with $\mathrm{ENE}(+)$. (from AJCC 8th Ed.) 